\title{
Global FDI Inflow and Its Implication across Economic Income Groups
}

\author{
Udi Joshua ${ }^{1}$ (), Mathew Ekundayo Rotimi ${ }^{1}$ and Samuel Asumadu Sarkodie ${ }^{2, *}$ (i) \\ 1 Department of Economics, Federal University Lokoja, Lokoja 1154, Nigeria; udijoshua@yahoo.com (U.J.); \\ drmathewrotimi@gmail.com (M.E.R.) \\ 2 Nord University Business School (HHN), Post Box 1490, 8049 Bodø, Norway \\ * Correspondence: asumadusarkodiesamuel@yahoo.com
}

Received: 5 October 2020; Accepted: 20 November 2020; Published: 22 November 2020

check for updates

\begin{abstract}
Foreign direct investment (FDI) as a driver of growth is important in today's globalized economy. It is extremely difficult for economies to grow sustainably without economic interactions outside their borders. However, there has been a debate on the impact of FDI inflow on economic expansion. Hence, this study investigated the influence of FDI on economic growth for a selection of 200 economies around the world for the period 1990-2018. We subdivided the sample into World Bank income group clusters to aid comparison across income blocs. The study employed panel estimation techniques including pooled ordinary least squares (POLS), dynamic panel estimation with fixed-effects and random-effects and generalized method of moments (GMM). The study found that FDI, debt stock and official development assistance are promoters of growth in the selected countries-although debt stock weakly impacts economic growth. In contrast, trade openness and exchange rates had a mixed (negative and positive) influence on economic growth. The study suggests that the creation of a conducive business environment and economic policies will attract FDI inflows. Additionally, borrowing from external sources could be minimized despite its perceived positive influence on growth to achieve financial independence.
\end{abstract}

Keywords: economic growth; external debts; foreign direct investment; official development assistance; trade openness

JEL Classification: F15; F43; F3; 014

\section{Introduction}

Generally, it is an established assertion that investment is a key component of economic growth in every economy as stated by the classic theory of economic growth. This means that for an economy to attain its desired growth and subsequent development, priority must be given to long-term investments. This could be either direct or indirect investment as well as local or foreign. Foreign direct investment (FDI) according to Joshua et al. (2020a) is the investment of foreign resources presumed to be a panacea for economic growth through its complementary role for the recipient country, particularly developing economies, which normally suffer from limited domestic resources. Developing economies receive the benefit of the spillover effect of FDI in the form of technology transfers and human capital development. The FDI received is expected to strengthen the domestic capital to match the total resources required for investment in the economy. This means that the level of domestic investment depends in part on the level of FDI inflow achieved in the recipient country.

However, while a considerable number of studies have been carried out on the association between FDI and economic growth, the impact of FDI on economic growth and how FDI projects economic growth remains equivocal. More importantly, Rjoub et al. (2017) avow that attracting FDI alone 
may not represent a wide-ranging panacea for generating economic growth. FDI inflow recently started experiencing a continuous fall across the global economies, which in effect is presumed to affect economic growth as reported by the United Nations Conference on Trade and Development [UNCTAD (2018)]. For instance, in 2000, FDI inflow rose to US $\$ 1.569$ trillion and sharply dropped to US\$737.213 billion in 2003. From 2004, FDI inflow began to record recovery and kept rising to the highest peak ever achieved in 2007, amounting to US\$3.136 trillion. This peak could not be sustained for long as global crises set in by 2008 leading to a drastic fall in FDI to US\$1.447 trillion in 2009. In 2011, FDI inflow witnessed another rise to US\$2.366 trillion and kept fluctuating until a significant increase was achieved in 2015, which amounted to US\$2.676 trillion. Unfortunately, from 2016 through 2017 to 2018, FDI inflow continuously trended downward at US\$3.471 trillion, US\$2.498 trillion, and US\$1.632 trillion, respectively. The amount of FDI dropped from US $\$ 2.676$ trillion in 2015 to US\$1.35 trillion in 2018.

Consequently, the UNCTAD (2018) asserts that developed economies experienced a higher rate of fall in FDI inflow than developing countries. In 2016, FDI inflow into developed countries fell by 10\%, amounting to US $\$ 671$ billion relative to 2015. Africa continued to witness a drastic fall from 2016 by $21 \%$, amounting to US $\$ 42$ billion, while Asia, which is the highest recipient in the world, witnessed stability of FDI inflow equivalent to US\$476 billion. This could not be sustained over time, however, as global crises continued to loom. Interestingly, the economic recovery that Latin America and the Caribbean witnessed in 2016 assisted in attracting an increase in FDI inflow by 8\% in 2017, amounting to US\$151 billion. Emerging economies recorded an increase in FDI inflow by 3\%. For instance, Africa recorded a $6 \%$ increase, Asia experienced an increase of $5 \%$, and developed economies witnessed a $37 \%$ decline amounting to US\$712 billion relative to 2015. FDI inflow to the United States declined by 18\%, while Canada recorded a decline of US\$38 billion between 2017 and 2018. While several studies have examined FDI economic growth nexus, the authors are not aware of any study investigating the global FDI inflow crises and economic growth relationship across income groups, particularly in the recent past during global crises. In view of this background, this study contributes to the literature by investigating the influence of FDI on economic growth in selected countries. Our study contributes to the existing literature by examining not only the FDI-led nexus among the income groups for the first time but also foreign aid as a control variable.

Consequently, this study set out to investigate the influence of FDI inflow on economic growth among the World Bank income clusters to achieve the following two specific objectives: first, to ascertain the level of the impact of FDI inflow on economic growth in the context of the global crises, and second, to reaffirm the validity of the modernization theory, which asserts that FDI inflow benefits emerging economies more than their developed counterparts. In short, the study aims to establish which of the World Bank income clusters are consistent with the assertion of the dependency or modernization theories.

The rest of this paper includes the empirical review, which follows this section. Data and methods, presentation of results and interpretation, and the conclusion and recommendations are presented in Section 3, Section 4, and Section 5, respectively.

\section{Literature Review}

It is traditionally believed that acquiring external capital such as FDI inflow and external loans will help augment domestic resources to meet domestic investment demands, thereby promoting the economic growth of home economies, particularly developing economies, as asserted by the modernization theory. However, this assertion is strongly opposed by the dependency theory, which argues against FDI inflow, a practice regarded as exploitative, especially for developing economies. For the sake of emphasis, the modernization theory originated from Max Weber (1864-1920) and was popularized by Talcott Parsons (1902-1979) (see Joshua et al. 2020b). The theory argues that traditional societies will experience development as they adopt more modern practices. On the other hand, the dependency theory credited to Hans Singer and Rauf Prebish argues that resources flow from a 
"periphery" of underdeveloped and poor economies to a "core" of rich economies, enriching the rich economies at the expense of the poor economies (see Joshua et al. 2020b).

In support of the modernization theory are studies such as Asongu and Odhiambo (2020) and Shahbaz et al. (2019). Buttressing their claim, they examined the FDI-induced hypothesis in Sub-Saharan Africa and found that FDI inflow promotes economic growth significantly. Similarly, Joshua et al. (2020) investigated the interaction between the said variables for the South African economy and found that FDI drives economic expansion in the country of study as supported by Shahbaz et al. (2019) and Joshua (2019). Sarkodie and Strezov (2019) estimated the relationship between FDI and economic development in developing nations. Their result proved that FDI inflow will contribute to emission in Indonesia, which is a threat to achieving economic development in the country. The study of Güngör and Ringim (2017) is similar to previous studies such as Shahbaz et al. (2019). Güngör and Ringim (2017) validated the FDI-induced nexus in Nigeria and concluded that FDI is a contributing factor to the course of economic growth. In a related study, Joshua (2019) adopted the autoregressive distributed lag (ARDL) approach to examine the interaction between GDP, FDI, and government expenditure in Nigeria. The empirical evidence shows that FDI inflow is essentially needed to complement the domestic resources to achieve economic advancement. Furthermore, Shahbaz et al. (2019) found that FDI inflow possesses a spillover effect, which is potent enough to transform the economic growth rate, concretizing the findings of Balcilar et al. (2019).

Masipa (2018) used the vector error correction procedure for the economy of South Africa. The result confirmed a positive interaction between FDI inflow and both economic growth and exchange rates. Rjoub et al. (2017) examined the impact of FDI inflow on economic growth in the landlocked economies of Sub-Saharan Africa from 1995 to 2013. The result proved that FDI inflow exhibits a significant positive impact on economic growth. Further evidence proves that FDI does not demonstrate a crowding out effect on domestic investment. Instead, FDI inflow and domestic investment play a substitution role in the region. This is supported by the work of Rjoub et al. (2017). The found a significant positive interaction between FDI inflow and economic growth in the Latin American countries.

Agrawal (2015) examined FDI-induced growth in Brazil, Russia, India, China, and South Africa by adopting panel cointegration and causality tests. The result confirmed the expected hypothesis. Duarte et al. (2017) aimed to empirical link economic growth, FDI inflow, and financial development in Cabo Verde using the dynamic ARDL for cointegration and the Granger causality test. The outcome validated that the FDI-led growth nexus is two-fold. First, the ARDL result shows that FDI exhibited a positive impact on economic growth coupled with the existence of long-run equilibrium. Secondly, only FDI inflow was found to exhibit a causal effect on economic growth.

Pegkas (2015) examined a similar case for the Eurozone economies using the dynamic ordinary least squares (DOLS) and the fully modified ordinary least squares (FMOLS) methods. The result proved a long-run cointegration between the series and that FDI significantly promotes economic growth in the study area. Iamsiraroj (2016) carried out a panel study on the FDI-led growth hypothesis. The outcome shows that FDI inflow positively influenced the economic growth of the study region. Further findings indicate a causal feedback effect between the variables. The study of Simionescu (2016) examined the interaction between FDI inflow and economic growth in the European Union from 2008 to 2014 during the economic recession. The result was a mixed outcome where FDI inflow acted as an agent of economic growth in some countries and did not in other countries. However, the overall result invalidated the FDI-led growth hypothesis. Shahzad et al. (2016) investigated the interaction between FDI inflow, terrorism, and economic growth in Pakistan. The result confirmed the long-run equilibrium link between the variables. Further findings showed a feedback causality. Shahbaz and Rahman (2012) studied a similar case for Pakistan and confirmed the case of long-term co-movement between the series. A further revelation proved that FDI inflow positively and significantly strengthens the path of economic growth. In a similar study, Gungor and Salih (2010) examined the said hypothesis and found evidence of an FDI-led nexus for Turkey, corroborated by Güngör and Ringim (2017). Similarly, 
Tshepo (2014) and Ahmad et al. (2015) subscribed to the FDI-induced growth hypothesis as supported by one of the early studies of the subject matter by Borensztein et al. (1998). The submission of Borensztein et al. (1998) maintained that FDI inflow influences economic growth faster than its domestic counterpart. This submission is supported by Shahbaz et al. (2019), Almfraji and Almsafir (2014), Omri and Kahouli (2013), Shahbaz and Rahman (2012), and Berthélemy and Demurger (2000)Berthélemy and Demurger Nair-Reichert and Weinhold (2001) submitted that FDI inflow is more effective in an open economy than a close one. Tang et al. (2019) found a unidirectional flow from FDI to domestic investment in China as well as a non-feedback link from FDI inflow to growth.

Additionally, Ayanwale (2007) and Joshua (2019) examined the interaction linking FDI inflow and economic growth, which indicates a positive but weak link between the series. Chakraborty and Nunnenkamp (2008) investigated the said hypothesis and found that FDI inflow impacts economic growth more through the service sector of China. Azman-Saini and Law (2010) maintained that to achieve the full potential effect of FDI inflow, a minimum financial improvement is required. Wang (2009) investigated the interaction connection between FDI inflow and the manufacturing sector. The results showed that FDI inflow positively influences economic growth via its effect on the manufacturing sector for the economies of twelve aligned Asian regions. This finding validates the work of Yao (2006) for China. Omri and Kahouli (2013) studied the subject matter for three regions and found a mutual link connecting economic growth with FDI inflow in the corresponding regions. This finding also validates Hermes and Hermes and Lensink (2003). A similar study for South Africa found evidence for the FDI-led growth hypothesis where FDI was noticed to serve as a complementary factor to its domestic counterpart (Fedderke and Romm 2006). Prasanna (2010) studied the causal link associated with FDI inflow and economic growth in India. The result shows that the direct influence of FDI inflow on domestic investment is positive and significant.

Similarly, the dependency theory asserts that external capital such as FDI inflow acts as an agent for capital flight, thereby affecting economic growth negatively. This view is supported by empirical studies such as Adams (2009). Abdouli and Hammami (2017) examined the FDI-led growth hypothesis in the Middle East and North Africa region. The outcome revealed that FDI inflow exhibits negative influence over economic growth in two economies, Egypt and Lebanon, among the MENA economies. The work of Adams (2009) found that FDI inflow weakens the path of economic growth in the short-term through its negative impact on domestic investment. Stanisic (2015) reviewed the relevant existing literature on the relationship between FDI inflow and economic growth in the Southeastern emerging countries. The outcome shows non-linkage between the two variables. Temiz and Gökmen (2014) investigated the impact of multi-national company investment on economic development in Turkey. The outcome indicates that these companies have no empirical link with economic development in Turkey both in the short and long run. Tang et al. (2019) found a unidirectional flow from FDI to domestic investment in China as well as a non-feedback link from FDI inflow to growth.

Other related studies reveal uncertainty as regards the potency of FDI inflow. For instance, Mohamed et al. (2017) investigated the said relationship in Malaysia. The study reveals the absence of causal interaction, similar to the work of Prasanna (2010). Prasanna (2010) found the uncertainty of the influence of FDI inflow over domestic investment in India. Fedderke and Romm (2006) studied the said hypothesis and revealed that FDI inflow promotes the process of capital flight from domestic economies confirming the work of Belloumi (2014) for Tunisia. The result further showed that the presumed influence of FDI inflow is controversial and a fallacy in Tunisia, corroborating the view Alfaro et al. (2009). Pandya and Sisombat (2017), Flora and Flora and Agrawal (2014), and Mehic et al. (2013) also subscribed to the negative impact of FDI inflow in their respective study areas. The study of Goh et al. (2017) supports the dependency theory, as does the study of Bezuidenhout (2009), confirming the studies of Khobai et al. (2017) and Mah (2010). On the same path, Joshua and Alola (2020) invalidated the causal link between FDI inflow and economic expansion in South Africa. Goh et al. (2017) submit that the potency of FDI inflow is uncertain, as supported by Joshua et al. (2020a, 2020b) contrasted the assertion that FDI drives economic advancement. 


\section{Data and Methods}

\subsection{Data}

The yearly information used in this study covers the period 1990-2018 for 200 countries clustered according to World Bank income clusters (Appendix A). The variables considered include GDP (constant 2010 US\$), trade openness (\% of GDP), foreign direct investment (BOP, current \$), external debt stocks (DOD, current 2010 US\$), official exchange rates (LCU per US\$, period average), and net official development assistance received (constant 2015 US\$). All data are sourced from the World Bank Development Indicators (2020). The choice of these variables was informed by theory and previous studies (See Cambazoğlu and Karaalp 2013; Latief and Lefen 2018; Rjoub et al. 2017). Following Rotimi and Ngalawa (2017), exchange rate means the expression of the prices of country-specific currencies in US dollars. The choice of the US dollar was informed by the fact that the US dollar is the most traded currency among all currencies (see Rotimi and Ngalawa 2017). Exchange rate (EXR) was included as a monetary instrument. Debt, according to Rotimi et al. (2019) is the sum of money owed, and GDP is an inflation-adjusted measure of all the goods and services produced at constant national prices for each country annually in a given base year. The inclusion of FDI, debt (DBT), official foreign development aid (ODA), and trade openness (TRO) was to examine the relationship of the selected countries with their business counterparts (see Joshua et al. 2020b).

\subsection{Model and Methods}

To achieve the objectives of this study, we analyzed a regression equation on the determinants of growth. The growth regression equation is functionally given as:

$$
\begin{gathered}
R G D P=f(F D I, D B T, E X R, O D A, T R O) \\
L R G D P_{i t}=\beta_{0}+\vartheta L R G D P_{i t-1}+\beta_{1} F D I_{i t}+\beta_{2} D B T_{i t}+\beta_{3} E X R_{i t}+\beta_{4} O D A_{i t}+\beta_{5} T R O_{i t}+\mu_{i t}
\end{gathered}
$$

where $\beta_{0}$ is intercept; $\vartheta, \beta_{1}, \beta_{2}, \beta_{3}, \beta_{4}$, and $\beta_{5}$ are the respective parameters for the determinants (LRGDP , FDI, DBT, EXR, ODA, and TRO) for growth; and $\mu_{i t}$ is the error term. $L R G D P_{i t-1}$ is a one period lag operator (previous year GDP growth); FDI, DBT, EXR, ODA, and TRO are foreign direct investment, debts, exchange rates, official foreign development aid, and trade openness, respectively.

All variables were converted to natural log. The panel of 200 countries was subdivided along with the four World Bank country income clusters: low-income, lower-middle-income, upper-middle-income, and high-income countries. The study employed a dynamic model to effectively establish the significance of the FDI inflow in economic growth. The fixed-effects (FE) and random-effects (RE) models were employed in this study. This was because they both allow for panel heterogeneities. Furthermore, the procedure complements the pooled ordinary least squares (POLS) method. Van Bon (2019) notes that dynamic characteristics similar to Equation (2) reveal that the country-specific fixed effects can be serially correlated with the lagged dependent variable, and some explanatory variables may be endogenous, hence resulting in estimation bias and inconsistency or spurious OLS. The dynamic specification removes the temporal autocorrelation in the residuals and prevents a spurious regression, which may lead to inconsistent estimators. However, to overcome the heterogeneity problem, the study employed the system generalized method of moments (Sys-GMM) dynamic model of Arellano and Bond (1991). The GMM model accounts for serial correlation endogeneity issues inherent in the regression (see Ullah et al. 2018; Akande and Kwenda 2017; Saini and Singhania 2018; Van Bon 2019). Buttressing this, Fiordelisi et al. (2015) avow that it is necessary to account for endogeneity issues in a regression to avoid issues like reverse simultaneity, causality, and variable omission regardless of the inclusion of a few control variables in the regression. This ensures the validity and robustness of the regression results (see Akande and Kwenda 2017).

This study pooled cross-sectional time series data of the sampled income group countries under consideration using GMM. This procedure is in line with Ullah et al. (2018). The choice of panel 
data analysis was informed by various benefits of the panel technique. For instance, a benefit that panel data estimation technique offers, identified by Baltagi (2008), is that panel data analysis accommodates the creation and analysis of more difficult behavioral models. Moreover, the technique provides for additional degrees of freedom, leads to better efficiency when compared to time series and cross-sectional data, and offers more explanatory analysis. Panel analysis generally means more variability, limited collinearity, and controlled heterogeneity within individual data (Baltagi 2008).

\section{Results and Discussion}

Most time macroeconomic variables fluctuate due to disturbances in economic activities. To avoid spurious analysis, data are subjected to stationarity tests to determine their stability. This study adopted different robust unit roots of Levin, Lin, and Chu (LLC) and Im, Pesaran, and Shin (IPS). The results as presented in Tables 1-4 indicate a mixed order of integration for all the regions under investigation.

Table 1. Levin, Lin, and Chu (LLC) and Im, Pesaran, and Shin (IPS) panel unit root tests for the low-income group.

\begin{tabular}{ccccc}
\hline \multirow{2}{*}{ Variable } & \multicolumn{2}{c}{$\begin{array}{c}\text { Levin, Lin, and Chu Unit Root Test } \\
\text { (Individual Intercept) }\end{array}$} & \multicolumn{2}{c}{$\begin{array}{c}\text { Im, Pesaran, and Shin Unit Root Test } \\
\text { (Individual Intercept) }\end{array}$} \\
\cline { 2 - 5 } & Order of Integration & $p$-Value & Order of Integration & $p$-Value \\
\hline GDP & I(1) & $0.0000^{* * *}$ & $\mathrm{I}(0)$ & $0.0000^{* * *}$ \\
FDI & $\mathrm{I}(0)$ & $0.0000^{* * *}$ & $\mathrm{I}(0)$ & $0.0000^{* * *}$ \\
DEBT & $\mathrm{I}(1)$ & $0.0000^{* * *}$ & $\mathrm{I}(1)$ & $0.0000^{* * *}$ \\
TRO & $\mathrm{I}(0)$ & $0.0000^{* * *}$ & $\mathrm{I}(0)$ & $0.0021^{* * *}$ \\
ODA & $\mathrm{I}(1)$ & $\mathrm{I}(1)$ & $0.0000^{* * *}$ \\
EXR & $\mathrm{I}(1)$ & $0.0000^{* * *}$ & $\mathrm{I}(0)$ & $0.0000^{* * *}$ \\
\hline
\end{tabular}

Source: Authors' computation using E-views 10.0 Statistical Package. “**** represents $1 \%$ significance level.

Table 2. LLC and IPS panel unit root tests for lower-middle income.

\begin{tabular}{ccccc}
\hline \multirow{2}{*}{ Variable } & $\begin{array}{r}\text { Levin, Lin, and Chu Unit Root Test } \\
\text { (Individual Intercept) }\end{array}$ & \multicolumn{2}{c}{$\begin{array}{c}\text { Im, Pesaran, and Shin Unit Root Test } \\
\text { (Individual Intercept) }\end{array}$} \\
\cline { 2 - 5 } & Order of Integration & $p$-Value & Order of Integration & $p$-Value \\
\hline GDP & $\mathrm{I}(1)$ & $0.0000^{* * *}$ & $\mathrm{I}(0)$ & $0.0000^{* * *}$ \\
FDI & $\mathrm{I}(0)$ & $0.0000^{* * *}$ & $\mathrm{I}(0)$ & $0.0000^{* * *}$ \\
DEBT & $\mathrm{I}(1)$ & $0.0000^{* * *}$ & $\mathrm{I}(1)$ & $0.0000^{* * *}$ \\
TRO & $\mathrm{I}(0)$ & $0.0000^{* * *}$ & $\mathrm{I}(0)$ & $0.0021^{* * *}$ \\
ODA & $\mathrm{I}(1)$ & $0.0000^{* * *}$ & $\mathrm{I}(1)$ & $0.0000^{* * *}$ \\
EXR & $\mathrm{I}(1)$ & $0.0000^{* * *}$ & $\mathrm{I}(0)$ & $0.0000^{* * *}$ \\
\hline
\end{tabular}

Source: Authors' computation using E-views 10.0 Statistical Package. “***” represents 1\% significance level.

Table 3. LLC and IPS panel unit root tests for upper-middle income.

\begin{tabular}{ccccc}
\hline \multirow{2}{*}{ Variable } & \multicolumn{2}{c}{$\begin{array}{c}\text { Levin, Lin, and Chu Unit Root Test } \\
\text { (Individual Intercept) }\end{array}$} & $\begin{array}{c}\text { Im, Pesaran, and Shin Unit Root Test } \\
\text { (Individual Intercept) }\end{array}$ \\
\cline { 2 - 5 } & Order of Integration & $p$-Value & Order of Integration & $p$-Value \\
\hline GDP & I(0) & $0.0000^{* * *}$ & $\mathrm{I}(1)$ & $0.0000^{* * *}$ \\
FDI & $\mathrm{I}(0)$ & $0.0054^{* * *}$ & $\mathrm{I}(0)$ & $0.0037^{* * *}$ \\
DEBT & $\mathrm{I}(0)$ & $0.0566^{* * *}$ & $\mathrm{I}(0)$ & $0.0550^{* *}$ \\
TRO & $\mathrm{I}(0)$ & $\mathrm{I}\left(0000^{* * *}\right.$ & $\mathrm{I}(0)$ & $0.0104^{* * *}$ \\
ODA & $\mathrm{O}(0)$ & $0.0000^{* * *}$ & $\mathrm{I}(1)$ & $0.0015^{* * *}$ \\
EXR & $\mathrm{I}(1)$ & $0.0000^{* * *}$ & $0.0879^{*}$ \\
\hline
\end{tabular}

Source: Authors' computation using E-views 10.0 Statistical Package. “***”, “**”, and “*** represents 1\%,5\%, and $1 \%$ significance levels. 
Table 4. LLC and IPS panel unit root tests for high-income.

\begin{tabular}{ccccc}
\hline \multirow{2}{*}{ Variable } & \multicolumn{2}{c}{$\begin{array}{c}\text { Levin, Lin, and Chu Unit Root Test } \\
\text { (Individual Intercept) }\end{array}$} & \multicolumn{2}{c}{$\begin{array}{c}\text { Im, Pesaran, and Shin Unit Root Test } \\
\text { (Individual Intercept) }\end{array}$} \\
\cline { 2 - 5 } & Order of Integration & $p$-Value & Order of Integration & $p$-Value \\
\hline GDP & $\mathrm{I}(1)$ & $0.0000^{* * *}$ & $\mathrm{I}(0)$ & $0.0000^{* * *}$ \\
FDI & $\mathrm{I}(0)$ & $0.0000^{* * *}$ & $\mathrm{I}(0)$ & $0.0000^{* * *}$ \\
DEBT & $\mathrm{I}(1)$ & $0.0000^{* * *}$ & $\mathrm{I}(1)$ & $0.0000^{* * *}$ \\
TRO & $\mathrm{I}(0)$ & $0.0000^{* * *}$ & $\mathrm{I}(0)$ & $0.0021^{* * *}$ \\
ODA & $\mathrm{I}(1)$ & $0.0000^{* * *}$ & $\mathrm{I}(1)$ & $0.0000^{* * *}$ \\
EXR & $\mathrm{I}(1)$ & $0.0000^{* * *}$ & $\mathrm{I}(0)$ & $0.0000^{* * *}$ \\
\hline
\end{tabular}

Source: Authors' computation using E-views 10.0 Statistical Package. "****” represents $1 \%$ significance level.

The pooled regression results for country clusters according to the World Bank income groups are presented in Table 5. Evidence from the results shows that FDI increases economic growth significantly across regions under investigation. A $1 \%$ rise in FDI increases growth by $0.062 \%, 0.17 \%, 0.12 \%$, and $0.68 \%$ in the low, lower-middle, upper-middle, and high-income countries. It appears that FDI drives growth best in high-income economies compared with low-income clusters, which may be connected to an improved and friendly business environment in developed countries. It is a fact that developed countries enjoy a relatively more stable economic and political environment than their emerging economy counterparts. This is strong enough to sustain investment visibility and profitability, thereby resulting in economic growth.

Table 5. Pooled OLS for comparative analysis across the four World Bank income clusters.

\begin{tabular}{ccccc}
\hline & Low-Income & Lower-Middle-Income & Upper-Middle Income & High-Income \\
\hline & Sub-regions' pooled OLS results (dep. variable: RGDP, log) & \\
\hline LDBT & $0.425^{* *}$ & $0.705^{* *}$ & $0.796^{* *}$ & -0.125 \\
& $(0.0389)$ & $(0.0242)$ & $(0.0243)$ & $(0.110)$ \\
\hline LEXR & $-0.0144^{* *}$ & $-0.0161^{* * *}$ & $0.0132^{* *}$ & $0.110^{* *}$ \\
& $(0.0130)$ & $(0.0065)$ & $(0.0107)$ & $(0.0465)$ \\
\hline LODA & $0.408^{* * *}$ & $0.132^{* * *}$ & $0.0524^{* * *}$ & $0.0623^{*}$ \\
& $(0.0325)$ & $(0.0281)$ & $(0.0173)$ & $(0.0513)$ \\
\hline LTRO & $-0.152^{*}$ & $-0.251^{* * *}$ & $-0.752^{* * *}$ & -0.783 \\
& $(0.0779)$ & $(0.0410)$ & $(0.0719)$ & $(0.130)$ \\
\hline LFDI & $0.0628^{* * *}$ & $0.175^{* * *}$ & $0.128^{* * *}$ & $0.686^{* * *}$ \\
& $(0.0183)$ & $(0.0160)$ & $(0.0260)$ & $(0.0827)$ \\
\hline Constant & 4.491 & 2.883 & 5.905 & 13.95 \\
& $(0.6900)$ & $(0.4600)$ & $(0.5790)$ & $(1.8410)$ \\
\hline Year Dummies & Yes & Yes & Yes & Yes \\
Observations & 614 & 1008 & 1132 & 128 \\
R-squared & 0.776 & 0.898 & 0.908 & 0.888 \\
\hline
\end{tabular}

Authors' computation. Notes: Robust standard errors in parentheses; ${ }^{* * *} p<0.01,{ }^{* *} p<0.05,{ }^{*} p<0.1$.

Debt stock drives economic growth in all country clusters except for high-income countries, where it demonstrates negative but insignificant influence over economic acceleration. Specifically, a $1 \%$ rise in debt increases economic growth by $0.42 \%, 0.70 \%$, and $0.79 \%$ in low-income, lower-middle-income, and upper-middle-income economies, respectively. Furthermore, as indicated by the findings, upper-middle-income countries benefit more from external debt than lower-middle-income regions. For the high-income economies, the result shows that debt could retard economic growth, as asserted by the modernization theory. 
Changes in exchange rates impede growth significantly in low-income and lower-middle-income countries, while it is favorable for growth in upper-middle-income and high-income.

Consequently, official development assistance boosts economic acceleration in all the income clusters. Specifically, a $1 \%$ increase in official development assistance induces growth by $0.40 \%, 0.13 \%$, $0.052 \%$, and $0.062 \%$ in low, lower-middle, upper-middle, and high-income countries, respectively. Development assistance provides supplementary income to support economic activities in the receiving countries, particularly the low-income economies as expected.

Trade openness demonstrates anti-economic growth in all four income clusters. A $1 \%$ increase in openness leads to a fall in growth by $0.15 \%, 0.25 \%, 0.75 \%$ and $0.78 \%$ in the low, lower-middle, upper-middle, and high-income countries, respectively. The findings prove that upper-middle countries suffer most from trade openness compared to other regions.

To account for heterogeneities in the model, this study adopted FE and RE estimation as presented in Table 6. Results from FE and RE investigation show that FDI acts as an influencer of economic expansion among all income clusters. However, FDI boosts growth mostly in high-income economies, as this cluster demonstrates the highest FDI growth elasticity of $0.68 \%$ followed by lower-middle-income countries with an elasticity between $0.034 \%$ to $0.044 \%$ and $0.025 \%$ to $0.062 \%$, and the least elasticity is within $0.021 \%$ to $0.027 \%$ for upper-middle-income economies. Surprisingly, FDI inflow influences economic growth negatively in a significant way for the high-income economies with the FE approach of $0.016 \%$, whereas external debt, though weakly, boosts economic growth in all the income clusters except the high-income countries where the impact is negative and insignificant.

Furthermore, exchange rate works against growth in all the income-classified regions except for the high-income economies.

Official development assistance, as shown by the FE method, exhibits a positive influence on economic growth only in the lower-middle-income economies, while the RF method proves that the official development assistance influenced growth positively in the low, lower-middle, and high-income economies. The results indicate that low-income countries derive more benefits from the foreign assistance than developed economies.

The coefficient for trade openness demonstrates mixed results for the low-income countries considering the result from the FE method, which is positive, while RE shows a negative impact. The findings further indicate an unfavorable outcome for high-income countries. However, a negative influence on growth is demonstrated within the high-income economies. The implication is that trade openness benefits emerging economies more than developed countries, which validates the modernization theory.

Table 7 presents the regression outcome for the full sample of 200 countries using the pooled OLS, fixed-effects (FE), random-effects (RE), and generalized method of moments (GMM) estimators. The outcome proves to be significantly consistent with the findings from the previous techniques.

The results show that FDI has a positive influence on growth in all 200 countries as expected. All estimates in the table show a significantly positive coefficient for FDI. A consistent flow of FDI into the world economy entails the availability of resources to complement the domestic ones for the expansion of ongoing economic activities in various countries. FDI attracts highly skilled manpower into host countries, which helps boost labor productivity and consequently economic growth as supported by studies such as Adams (2009) for 42 Sub-Saharan African countries and Pegkas (2015) for 18 countries in the Eurozone.

Consequently, the results show that debt stock is an important determinant of growth in all 200 countries as demonstrated by its positive significant coefficient. This confirmed the theoretical assertion that external borrowings are mainly injected into the productive stream of the economy, thereby yielding a maximum result that will assist in promoting economic growth (Bakar and Hassan 2008). 
Table 6. Fixed- and random-effects estimates for comparative analysis across the four World Bank income clusters.

\begin{tabular}{|c|c|c|c|c|c|c|c|c|}
\hline \multicolumn{9}{|c|}{ (Dep. Variable: LRGDP, log) } \\
\hline & Low-Income & $\begin{array}{l}\text { Lower-Middle- } \\
\text { Income }\end{array}$ & $\begin{array}{l}\text { Upper-Middle } \\
\text { Income }\end{array}$ & High-Income & Low-Income & $\begin{array}{l}\text { Lower-Middle- } \\
\text { Income }\end{array}$ & $\begin{array}{l}\text { Upper-Middle } \\
\text { Income }\end{array}$ & High-Income \\
\hline & \multicolumn{4}{|c|}{$\begin{array}{l}\text { Fixed Effects } \\
\end{array}$} & \multicolumn{4}{|c|}{ Random Effects } \\
\hline LDBT & $\begin{array}{l}0.0929^{* *} \\
(0.0503)\end{array}$ & $\begin{array}{l}0.0692 * * \\
(0.0412)\end{array}$ & $\begin{array}{l}0.128^{* *} \\
(0.0274)\end{array}$ & $\begin{array}{c}-0.0938^{* *} \\
(0.0307)\end{array}$ & $\begin{array}{c}0.425^{*} \\
(0.0895)\end{array}$ & $\begin{array}{l}0.138^{* *} \\
(0.0448)\end{array}$ & $\begin{array}{l}0.167^{* *} \\
(0.0305)\end{array}$ & $\begin{array}{l}-0.125 \\
(0.221)\end{array}$ \\
\hline LEXR & $\begin{array}{c}-0.0134^{* *} \\
(0.0280)\end{array}$ & $\begin{array}{c}-0.0305 * \\
(0.0180)\end{array}$ & $\begin{array}{c}-0.0132^{* * *} \\
(0.00816)\end{array}$ & $\begin{array}{c}-0.128^{* * *} \\
(0.0305)\end{array}$ & $\begin{array}{c}-0.0144^{* *} \\
(0.0437)\end{array}$ & $\begin{array}{c}-0.0281 * * \\
(0.018)\end{array}$ & $\begin{array}{l}-0.0155^{*} \\
(0.00826)\end{array}$ & $\begin{array}{l}0.110 * \\
(0.0746)\end{array}$ \\
\hline LODA & $\begin{array}{c}-0.019^{* *} \\
(0.0439) \\
\end{array}$ & $\begin{array}{l}0.0309^{* *} \\
(0.0240)\end{array}$ & $\begin{array}{c}-0.0317^{*} \\
(0.0173) \\
\end{array}$ & $\begin{array}{l}-0.0106^{*} \\
(0.00514)\end{array}$ & $\begin{array}{l}0.408^{* * *} \\
(0.0814)\end{array}$ & $\begin{array}{l}0.0507^{* *} \\
(0.0257) \\
\end{array}$ & $\begin{array}{c}-0.026^{* *} \\
(0.0165) \\
\end{array}$ & $\begin{array}{l}0.0623 * \\
(0.084)\end{array}$ \\
\hline LTRO & $\begin{array}{l}0.0820 * \\
(0.0867)\end{array}$ & $\begin{array}{c}0.0729^{* * *} \\
(0.0202)\end{array}$ & $\begin{array}{l}0.0227 * \\
(0.0643)\end{array}$ & $\begin{array}{c}-0.0559 * * \\
(0.0598)\end{array}$ & $\begin{array}{l}-0.152 \\
(0.206)\end{array}$ & $\begin{array}{c}0.0448^{*} \\
(0.023)\end{array}$ & $\begin{array}{c}-0.016^{*} \\
(0.062)\end{array}$ & $\begin{array}{l}-0.783 \\
(0.254)\end{array}$ \\
\hline LFDI & $\begin{array}{l}0.0258^{* *} \\
(0.0112)\end{array}$ & $\begin{array}{l}0.0349^{* * *} \\
(0.00814)\end{array}$ & $\begin{array}{l}0.0212 * * * \\
(0.00703)\end{array}$ & $\begin{array}{c}-0.0002^{* *} \\
(0.0129)\end{array}$ & $\begin{array}{l}0.0628^{* *} \\
(0.0293)\end{array}$ & $\begin{array}{c}0.0440^{* * *} \\
(0.008)\end{array}$ & $\begin{array}{c}0.0272 * * * \\
(0.008)\end{array}$ & $\begin{array}{c}0.686^{* * *} \\
(0.119)\end{array}$ \\
\hline Constant & $\begin{array}{l}19.66 \\
(1.395)\end{array}$ & $\begin{array}{l}20.08 \\
(0.955)\end{array}$ & $\begin{array}{c}20.80 \\
(0.669)\end{array}$ & $\begin{array}{l}23.78 \\
(0.145)\end{array}$ & $\begin{array}{l}4.491 \\
(2.150)\end{array}$ & $\begin{array}{l}18.04 \\
(1.091)\end{array}$ & $\begin{array}{l}19.91 \\
(0.888)\end{array}$ & $\begin{array}{l}13.95 \\
(2.644)\end{array}$ \\
\hline Year Dummies & Yes & Yes & Yes & Yes & Yes & Yes & Yes & Yes \\
\hline Observations & 614 & 1008 & 1132 & 128 & 614 & 1008 & 1132 & 128 \\
\hline R-squared & 0.825 & 0.890 & 0.858 & 0.948 & & & & \\
\hline Country ID & 26 & 42 & 48 & 15 & 26 & 42 & 48 & 15 \\
\hline
\end{tabular}

Authors' computation. Notes: Robust standard errors in parentheses; ${ }^{* * *} p<0.01{ }^{* *} p<0.05{ }^{*} p<0.1$ 
Table 7. Results for main model estimation across several techniques compared with system GMM.

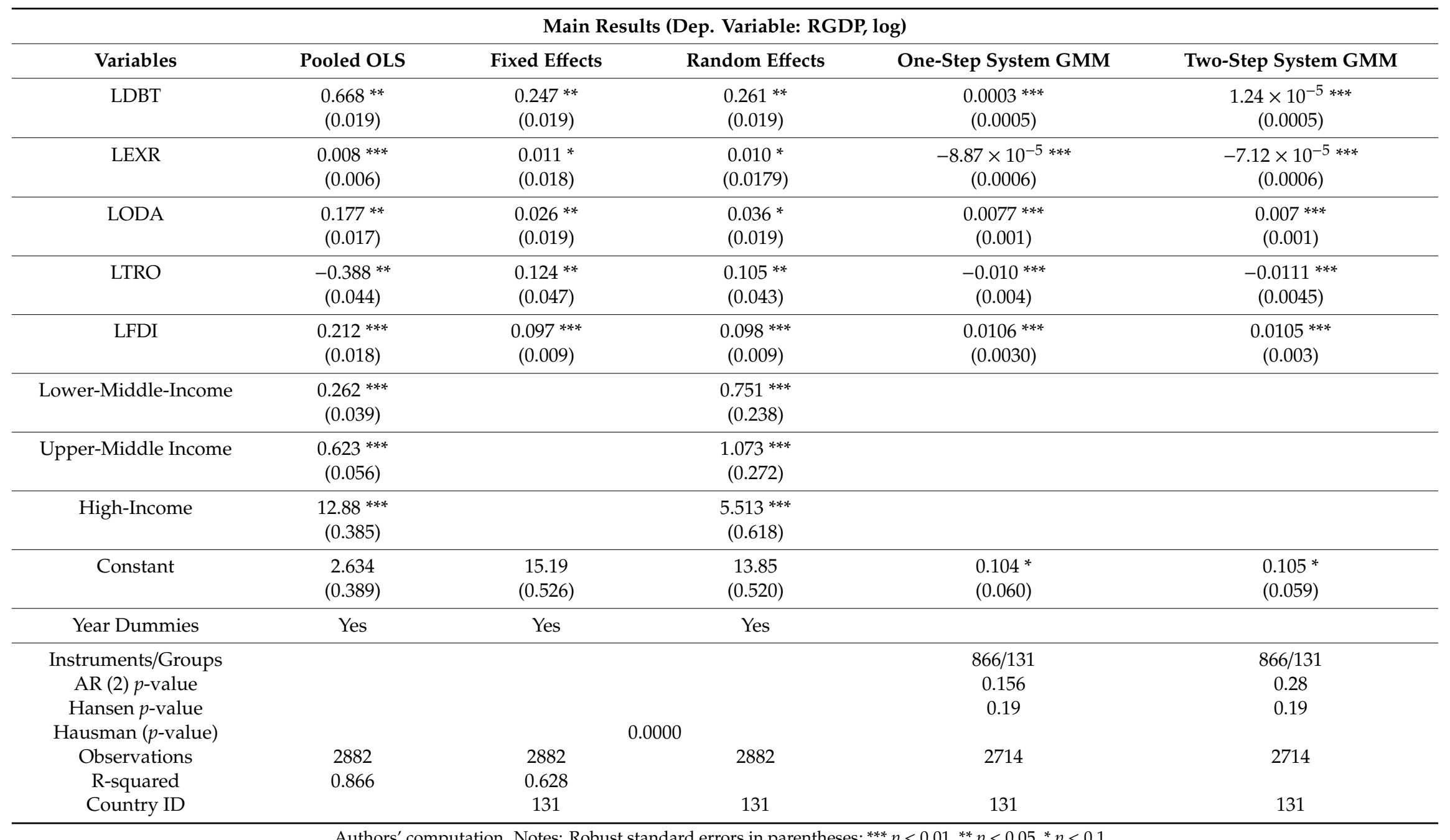

Authors' computation. Notes: Robust standard errors in parentheses; ${ }^{* * *} p<0.01,{ }^{* *} p<0.05,{ }^{*} p<0.1$. 
Exchange rates demonstrate a positive significant influence on economic growth for the selected countries as demonstrated by the OLS, FE, and RE estimators, while the GMM indicates a negative effect of exchange rates and economic growth.

On the other hand, official development assistance appears to be a driver of economic growth across 200 countries. This entails that official development assistance matters in the world economy, especially for developing countries, some of which have as much as between $5 \%$ to $10 \%$ development assistance as a share of GDP.

In confirmation of the previous findings, trade openness demonstrates a mixed outcome, where a negative and significant coefficient is estimated by the pooled OLS and GMM estimates, while the FE and RE estimates reveal a positive and significant coefficient for LTRO. Studies such as Rigobon and Rodrik (2005) for 242 countries concluded that openness harms growth. These mixed results reflect the work of Das and Paul (2011) for 12 Asian economies, which supported the negative impact of trade openness, while Yeboah et al. (2012) for 38 African countries agree that openness has a positive influence on growth.

\section{Conclusions}

The importance of global economic interactions in today's global economy cannot be overemphasized. FDI, debt, trade, and exchange rates have a significant influence on economic activities in almost all countries. However, debate still lingers on the impact of certain determinants of growth such as external debt and trade openness-as several policymakers differ on which position various countries should take. To contribute to the argument, this study carried out a study on the impact of FDI, external debt, trade openness, official development assistance, and exchange rates on economic growth for 200 countries spanning 1990 to 2018. These countries were subdivided into World Bank income clusters for comparative analysis. The study utilized panel estimations like the pooled OLS and dynamic panel estimations like the fixed-effects, random-effects, and GMM methods.

The findings revealed that FDI inflow, external debt, and official development assistance are key drivers of growth in all the 200 selected countries. However, the effect of FDI is more noticeable across emerging economies compared to developed economies. This validates the assertion of the modernization theory, which posits that FDI is a panacea for economic advancement, particularly among developing economies. Similarly, governments, especially from low-income countries, seek debt and development assistance from unilateral and multilateral agencies to boost domestic resources to match the investment demand. On the other hand, trade openness and exchange rate demonstrate a mixed effect (positive and negative) on economic growth with the latter proving to be insignificant.

This study suggests that to sustain economic growth through FDI, countries could adopt policies that will create an enabling political and economic environment suitable for businesses and economic activities to thrive. Such policy includes maintaining stable exchange rates and major infrastructural development. Strong financial and legal institutions are attractive scenes for foreign investors. On the other hand, except in critical circumstances, countries should minimize borrowing from foreign economies as a measure to avoid possible debt traps and their adverse effect on economic growth. Abstinence from debt would enable economies to achieve financial self-sustainability and independence. Furthermore, effort should be made towards mobilizing domestic resources to resolve economic challenges. This will build economies to a self-sustainable level of development, which is a major target of most global governmental authorities.

Author Contributions: Conceptualization, U.J.; methodology, U.J. and M.E.R.; software U.J.; validation, U.J.; formal analysis, U.J. and M.E.R.; X.X.; data curation, U.J.; writing—original draft preparation, U.J., M.E.R., S.A.S.; writing-review and editing, S.A.S.; supervision, S.A.S.; funding acquisition, S.A.S. All authors have read and agreed to the published version of the manuscript.

Funding: Open Access funding provided by Nord University.

Conflicts of Interest: The authors declare no conflict of interest. 


\section{Appendix A}

Table A1. List of countries in sample.

\begin{tabular}{|c|c|c|c|}
\hline Low-Income & Lower-Middle-Income & Upper-Middle Income & High-Income \\
\hline Afghanistan & Angola & Albania & Antigua and Barbuda \\
\hline Benin & Bangladesh & Algeria & Aruba \\
\hline Burkina Faso & Bhutan & Argentina & Australia \\
\hline Burundi & Bolivia & Armenia & Austria \\
\hline Central African Republic & Cabo Verde & Azerbaijan & Bahamas, The \\
\hline Chad & Cambodia & Belarus & Bahrain \\
\hline Congo, Dem. Rep. & Cameroon & Belize & Barbados \\
\hline Eritrea & Comoros & Bosnia and Herzegovina & Belgium \\
\hline Ethiopia & Congo, Rep. & Botswana & Bermuda \\
\hline Gambia, The & Cote d'Ivoire & Brazil & Brunei Darussalam \\
\hline Guinea & Djibouti & Bulgaria & Canada \\
\hline Guinea-Bissau & Egypt, Arab Rep. & China & Cayman Islands \\
\hline Haiti & El Salvador & Colombia & Chile \\
\hline Korea, Dem. People's Rep. & Eswatini & Costa Rica & Croatia \\
\hline Liberia & Ghana & Cuba & Cyprus \\
\hline Madagascar & Honduras & Dominica & Czech Republic \\
\hline Malawi & India & Dominican Republic & Denmark \\
\hline Mali & Indonesia & Ecuador & Estonia \\
\hline Mozambique & Kenya & Equatorial Guinea & Finland \\
\hline Nepal & Kiribati & Fiji & France \\
\hline Niger & Kyrgyz Republic & Gabon & French Polynesia \\
\hline Rwanda & Lao PDR & Georgia & Germany \\
\hline Sierra Leone & Lesotho & Grenada & Greece \\
\hline Somalia & Mauritania & Guatemala & Hong Kong SAR, China \\
\hline South Sudan & Micronesia, Fed. Sts. & Guyana & Hungary \\
\hline Syrian Arab Republic & Moldova & Iran, Islamic Rep. & Iceland \\
\hline Tajikistan & Mongolia & Iraq & Ireland \\
\hline Tanzania & Morocco & Jamaica & Israel \\
\hline Togo & Myanmar & Jordan & Italy \\
\hline Uganda & Nicaragua & Kazakhstan & Japan \\
\hline \multirow[t]{34}{*}{ Yemen, Rep. } & Nigeria & Kosovo & Korea, Rep. \\
\hline & Pakistan & Lebanon & Kuwait \\
\hline & Papua New Guinea & Libya & Latvia \\
\hline & Philippines & Malaysia & Lithuania \\
\hline & Sao Tome and Principe & Maldives & Luxembourg \\
\hline & Senegal & Marshall Islands & Macao SAR, China \\
\hline & Solomon Islands & Mauritius & Malta \\
\hline & Sudan & Mexico & Netherlands \\
\hline & Timor-Leste & Montenegro & New Caledonia \\
\hline & Tunisia & Namibia & New Zealand \\
\hline & Ukraine & Nauru & Northern Mariana Islands \\
\hline & Uzbekistan & North Macedonia & Norway \\
\hline & Vanuatu & Paraguay & Oman \\
\hline & Vietnam & Peru & Palau \\
\hline & West Bank and Gaza & Romania & Panama \\
\hline & Zambia & Russian Federation & Poland \\
\hline & Zimbabwe & Samoa & Portugal \\
\hline & & Serbia & Puerto Rico \\
\hline & & South Africa & Qatar \\
\hline & & Sri Lanka & San Marino \\
\hline & & St. Lucia & Saudi Arabia \\
\hline & & St. Vincent and the Grenadines & Seychelles \\
\hline & & Suriname & Singapore \\
\hline & & Thailand & Slovak Republic \\
\hline & & Tonga & Slovenia \\
\hline & & Turkey & Spain \\
\hline & & Turkmenistan & St. Kitts and Nevis \\
\hline & & Venezuela, RB & Sweden \\
\hline & & & Switzerland \\
\hline & & & Trinidad and Tobago \\
\hline & & & United Arab Emirates \\
\hline & & & United Kingdom \\
\hline & & & United States \\
\hline & & & Uruguay \\
\hline
\end{tabular}




\section{References}

Abdouli, Mohamed, and Sami Hammami. 2017. The impact of FDI inflows and environmental quality on economic growth: An empirical study for the MENA countries. Journal of the Knowledge Economy 8: 254-78. [CrossRef]

Adams, Samuel. 2009. Foreign direct investment, domestic investment, and economic growth in Sub-Saharan Africa. Journal of Policy Modeling 31: 939-49. [CrossRef]

Agrawal, Gaurav. 2015. Foreign direct investment and economic growth in BRICS economies: A panel data analysis. Journal of Economics, Business and Management 3: 421-24. [CrossRef]

Ahmad, Fayyaz, Muhammad Umar Draz, and Su-Chang Yang. 2015. Causality Nexus of Exports, FDI and Economic Growth: A Panel Data Analysis of the ASEAN Region. FDI and Economic Growth: A Panel Data Analysis of the ASEAN Region (October 8, 2015). Available online: http://dx.doi.org/10.2139/ssrn.2675793 (accessed on 20 March 2020).

Akande, Joseph Olorunfemi, and Farai Kwenda. 2017. Does competition cause stability in banks? SFA and GMM application to Sub-Saharan Africa commercial banks. Journal of Economics and Behavioral Studies 9: 173-86. [CrossRef]

Alfaro, Laura, Sebnem Kalemli-Ozcan, and Selin Sayek. 2009. FDI, productivity and financial development. World Economy 32: 111-35. [CrossRef]

Almfraji, Mohammad Amin, and Mahmoud Khalid Almsafir. 2014. Foreign direct investment and economic growth literature review from 1994 to 2012. Procedia-Social and Behavioral Sciences 129: 206-13. [CrossRef]

Arellano, Manuel, and Stephen Bond. 1991. Some tests of specification for panel data: Monte Carlo evidence and an application to employment equations. The Review of Economic Studies 58: 277-97. [CrossRef]

Asongu, Simplice A., and Nicholas M. Odhiambo. 2020. Foreign direct investment, information technology and economic growth dynamics in Sub-Saharan Africa. Telecommunications Policy 44: 101838. [CrossRef]

Ayanwale, Adeolu B. 2007. FDI and economic growth: Evidence from Nigeria. Available online: https: //publications.aercafricalibrary.org/handle/123456789/22 (accessed on 20 March 2020).

Azman-Saini, Wan Ngah Wan, and Siong Hook Law. 2010. FDI and economic growth: New evidence on the role of financial markets. Economics Letters 107: 211-13. [CrossRef]

Bakar, Abu, and Sallahuddin Hassan. 2008. Empirical Evaluation on External debt of Malaysia. International Business and Economics Research Journal 7: 95-108. [CrossRef]

Balcilar, Mehmet, Zeynel Abidin Ozdemir, and Muhammad Shahbaz. 2019. On the time-varying links between oil and gold: New insights from the rolling and recursive rolling approaches. International Journal of Finance $\mathcal{E}$ Economics 24: 1047-65.

Baltagi, Badi. 2008. Econometric Analysis of Panel Data. Chichester: John Wiley \& Sons.

Belloumi, Mounir. 2014. The relationship between trade, FDI and economic growth in Tunisia: An application of the autoregressive distributed lag model. Economic Systems 38: 269-87. [CrossRef]

Berthélemy, Jean-Claude, and Sylvie Demurger. 2000. Foreign direct investment and economic growth: theory and application to China. Review of Development Economics 4: 140-55. [CrossRef]

Bezuidenhout, Henri. 2009. A regional perspective on aid and FDI in Southern Africa. International Advances in Economic Research 15: 310-21. [CrossRef]

Borensztein, Eduardo, Jose De Gregorio, and Jong-Wha Lee. 1998. How does foreign direct investment affect economic growth? Journal of International Economics 45: 115-35. [CrossRef]

Cambazoğlu, Birgül, and Hacer Simay Karaalp. 2013. The External Finance Premium and the Financial Accelerator: The Case of Turkey. International Journal of Economic Sciences and Applied Research 6: 103-21.

Chakraborty, Chandana, and Peter Nunnenkamp. 2008. Economic reforms, FDI, and economic growth in India: a sector level analysis. World Development 36: 1192-212. [CrossRef]

Das, Anupam, and Biru Paksha Paul. 2011. Openness and growth in emerging Asian economies: Evidence from GMM estimations of a dynamic panel. Economics Bulletin 31: 2219-28.

Duarte, Leandro do Rosário Viana, Yin Kedong, and Li Xuemei. 2017. The relationship between FDI, economic growth and financial development in Cabo Verde. International Journal of Economics and Finance 9: 132-42. [CrossRef]

Fedderke, Johannes W., and Aylit T. Romm. 2006. Growth impact and determinants of foreign direct investment into South Africa, 1956-2003. Economic Modelling 23: 738-60. [CrossRef]

Fiordelisi, Franco, Davide Salvatore Mare, and Philip Molyneux. 2015. State-Aid, Stability and Competition in European Banking. Stability and Competition in European Banking (September 12, 2015). Available online: http://dx.doi.org/10.2139/ssrn.2676634 (accessed on 20 March 2020). 
Flora, Preeti, and Gaurav Agrawal. 2014. Foreign direct investment (FDI) and economic growth relationship among highest FDI recipient Asian economies: A panel data analysis. International Business Management 8: 126-32.

Goh, Soo Khoon, Chung Yan Sam, and Robert McNown. 2017. Re-examining foreign direct investment, exports, and economic growth in Asian economies using a bootstrap ARDL test for cointegration. Journal of Asian Economics 51: 12-22. [CrossRef]

Gungor, Hasan, and Katircioglu Salih. 2010. Financial development, FDI and real income growth in Turkey: An empirical investigation from the bounds tests and causality analysis. Actual Problems of Economics 11: 215-25.

Güngör, Hasan, and Salim Hamza Ringim. 2017. Linkage between foreign direct investment, domestic investment and economic growth: Evidence from Nigeria. International Journal of Economics and Financial Issues 7: 97-104.

Hermes, Niels, and Robert Lensink. 2003. Foreign direct investment, financial development and economic growth. The Journal of Development Studies 40: 142-63. [CrossRef]

Iamsiraroj, Sasi. 2016. The foreign direct investment-Economic growth nexus. International Review of Economics $\mathcal{E}$ Finance 42: 116-33.

Joshua, Udi. 2019. An ARDL Approach to the Government Expenditure and Economic Growth Nexus in Nigeria. Academic Journal of Economic Studies 5: 152-60.

Joshua, Udi, and Andrew Adewale Alola. 2020. Accounting for environmental sustainability from coal-led growth in South Africa: the role of employment and FDI. Environmental Science and Pollution Research 27: 17706-16. [CrossRef]

Joshua, Udi, Festus Fatai Adedoyin, and Samuel Asumadu Sarkodie. 2020a. Examining the external-factors-led growth hypothesis for the South African economy. Heliyon 6: e04009. [CrossRef]

Joshua, Udi, Oladimeji Salami, and Andrew Adewale Alola. 2020b. Toward the path of economic expansion in Nigeria: The role of trade globalization. Journal of Labor and Society 23: 205-20. [CrossRef]

Khobai, Hlalefang, Nicolene Hamman, Thando Mkhombo, Simba Mhaka, Nomahlubi Mavikela, and Andrew Phiri. 2017. The FDI-growth nexus in South Africa: A re-examination using quantile regression approach. Studia Universitatis Babes-Bolyai Oeconomica 63: 33-55. [CrossRef]

Latief, Rashid, and Lin Lefen. 2018. The effect of exchange rate volatility on international trade and foreign direct investment (FDI) in developing countries along "one belt and one road". International Journal of Financial Studies 6: 86. [CrossRef]

Mah, Jai S. 2010. Foreign direct investment inflows and economic growth of China. Journal of Policy Modeling 32: 155-58. [CrossRef]

Masipa, Tshepo S. 2018. The relationship between foreign direct investment and economic growth in South Africa: Vector error correction analysis. Acta Commercii 18: 1-8. [CrossRef]

Mehic, Eldin, Sabina Silajdzic, and Vesna Babic-Hodovic. 2013. The impact of FDI on economic growth: Some evidence from southeast Europe. Emerging Markets Finance and Trade 49: 5-20. [CrossRef]

Mohamed, Masoud Rashid, Keshminder Singh Jit Singh, and Chung-Yee Liew. 2017. Impact of foreign direct investment \& domestic investment on economic growth of Malaysia. Malaysian Journal of Economic Studies 50: 21-35.

Nair-Reichert, Usha, and Diana Weinhold. 2001. Causality tests for cross-country panels: A New look at FDI and economic growth in developing countries. Oxford Bulletin of Economics and Statistics 63: 153-71. [CrossRef]

Omri, Anis, and Bassem Kahouli. 2013. Causal relationships between energy consumption, foreign direct investment and economic growth: Fresh evidence from dynamic simultaneous-equations models. Energy Policy 67: 913-22. [CrossRef]

Pandya, Viral, and Sommala Sisombat. 2017. Impacts of Foreign Direct Investment on Economic Growth: Empirical Evidence from Australian Economy. International Journal of Economics and Finance 9: 121. [CrossRef]

Pegkas, Panagiotis. 2015. The impact of FDI on economic growth in Eurozone countries. The Journal of Economic Asymmetries 12: 124-32. [CrossRef]

Prasanna, N. 2010. Direct and indirect impact of foreign direct investment (FDI) on domestic investment (DI) in India. Journal of Economics 1: 77-83. [CrossRef]

Rigobon, Roberto, and Dani Rodrik. 2005. Rule of law, democracy, openness, and income: Estimating the interrelationships1. Economics of transition 13: 533-64. [CrossRef]

Rjoub, Husam, Mehmet Aga, Ahmad Abu Alrub, and Murad Bein. 2017. Financial reforms and determinants of FDI: evidence from landlocked countries in Sub-Saharan Africa. Economies 5: 1. [CrossRef] 
Rotimi, Mathew Ekundayo, and Harold Ngalawa. 2017. Oil price shocks and economic performance in Africa's oil exporting countries. Acta Universitatis Danubius. OEconomica 13: 169-88.

Rotimi, Mathew E., Harold Ngalawa, and A. Adebayo. 2019. Oil Price Shocks and Exchange Rates in Africa's Oil Exporting Countries: Forecasting Model. Available online: https://buff.ly/2UPj078 (accessed on 20 March 2020).

Saini, Neha, and Monica Singhania. 2018. Determinants of FDI in developed and developing countries: A quantitative analysis using GMM. Journal of Economic Studies 45: 348-82. [CrossRef]

Sarkodie, Samuel Asumadu, and Vladimir Strezov. 2019. Effect of foreign direct investments, economic development and energy consumption on greenhouse gas emissions in developing countries. Science of the Total Environment 646: 862-71. [CrossRef]

Shahbaz, Muhammad, and Mohammad Mafizur Rahman. 2012. The dynamic of financial development, imports, foreign direct investment and economic growth: cointegration and causality analysis in Pakistan. Global Business Review 13: 201-19. [CrossRef]

Shahbaz, Muhammad, Daniel Balsalobre-Lorente, and Avik Sinha. 2019. Foreign direct Investment- $\mathrm{CO}_{2}$ emissions nexus in Middle East and North African countries: Importance of biomass energy consumption. Journal of Cleaner Production 217: 603-14. [CrossRef]

Shahzad, Syed Jawad Hussain, Muhammad Zakaria, Mobeen Ur Rehman, Tanveer Ahmed, and Bashir Ahmed Fida. 2016. Relationship between FDI, terrorism and economic growth in Pakistan: pre and post 9/11 analysis. Social Indicators Research 127: 179-94. [CrossRef]

Simionescu, Mihaela. 2016. The relation between economic growth and foreign direct investment during the economic crisis in the European Union. Zbornik Radova Ekonomskog Fakulteta u Rijeci: Časopis za Ekonomsku Teoriju i Praksu 34: 187-213. [CrossRef]

Stanisic, Nedad. 2015. Do foreign direct investments increase the economic growth of Southeastern European transition economies? South-Eastern Europe Journal of Economics 6: 29-38.

Tang, Vanessa T., Fiona Tregenna, and Johane Dikgang. 2019. Trade Openness and Economic Growth in Mauritius. In Development and Sustainable Growth of Mauritius. Cham: Palgrave Macmillan, pp. 69-104.

Temiz, Dilek, and Aytaç Gökmen. 2014. FDI inflow as an international business operation by MNCs and economic growth: An empirical study on Turkey. International Business Review 23: 145-54. [CrossRef]

Tshepo, Masipa. 2014. The impact of foreign direct investment on economic growth and employment in South Africa: A time series analysis. Mediterranean Journal of Social Sciences 5: 18.

Joshua, Udi, Festus Victor Bekun, and Samuel Asumadu Sarkodie. 2020. New insight into the causal linkage between economic expansion, FDI, coal consumption, pollutant emissions and urbanization in South Africa. Environmental Science and Pollution Research 27: 18013-24. [CrossRef] [PubMed]

Ullah, Subhan, Pervaiz Akhtar, and Ghasem Zaefarian. 2018. Dealing with endogeneity bias: The generalized method of moments (GMM) for panel data. Industrial Marketing Management 71: 69-78. [CrossRef]

UNCTAD. 2018. FDI/MNE Database. Available online: https://buff.ly/2J1E33F (accessed on 20 March 2020).

Van Bon, Nguyen. 2019. Effects of Institutional Quality on FDI in Provinces of Vietnam: Empirical Evidence Based on Differenced Panel GMM. Journal of Economic Development 22: 26-45. [CrossRef]

Wang, M. 2009. Manufacturing FDI and economic growth: evidence from Asian economies. Applied Economics 41: 991-1002. [CrossRef]

World Bank Development Indicators. 2020. Available online: http://databank.worldbank.org (accessed on 20 January 2020).

Yao, S. 2006. On economic growth, FDI and exports in China. Applied Economics 38: 339-51. [CrossRef]

Yeboah, Osei-Agyeman, Cephas B. Naanwaab, Shaik Saleem, and Akua S. Akuffo. 2012. Effects of Trade Openness on Economic Growth: The Case of African Countries (No. 1372-2016-109007). Available online: https://ageconsearch.umn.edu/record/119795/ (accessed on 20 March 2020).

Publisher's Note: MDPI stays neutral with regard to jurisdictional claims in published maps and institutional affiliations. 